International Journal of Applied Agricultural Research

ISSN 0973-2683 Volume 12, Number 1 (2017) pp. 77-86

(C) Research India Publications

https://dx.doi.org/10.37622/IJAAR/12.1.2017.77-86

\title{
Analysis of Digital Media Compatibility with Farmers in Maharashtra and Recommendation of Service Provider Design Framework 'E-Krishimitra'
}

\author{
Prof. Sushopti Gawade \\ Research Scolor, Faculty of Engineering \\ PAHER ,Udaipur, Rajasthan, India. \\ Dr. Varsha Turkar \\ IEEE Senior Member \\ Vidyalankar Institute of Technology, Mumbai
}

\begin{abstract}
India is one of the world's fastest growing economy. Farming has been and will always remain a highly unorganized sector. Many of the systems are passed down through generations. Next generations follow the age old provided methods of farming as it is. To take intelligent and smart decisions about yields and crop gains, Government of India has taken very good initiatives with the help of information and communication technologies (ICT) which has seen enormous growth recently. ICT is essential tool for economic development. In India Most of the population lives in rural area. Agricultural experts are not practically available for them. In spite of numerous efforts taken by Government, because of digital illiteracy, farmers are not aware of different schemes of agriculture available for them. To improve usability of knowledge shared by different digital media and to minimize digital divide this research focuses to understand the compatibility with digital media or information and communication technologies available in rural areas of Maharashtra. Which can help us to design and implement better service provider tools. Which can reduce digital divide, usability issues of expert systems in agriculture, linguistic problem in geographical diversity of India and provide better solution that can act as an Expert, providing intelligent and smart decisions.
\end{abstract}

Keywords: Digital divide, geographical diversity, ICT, Usability, EKrishimitra. 


\section{NOMENCLATURE}

ICT : Information and communication Technology

Govt. : Government

TV : Television

IVR : Interactive voice response

IASRI :Indian Agricultural Statistical Research Institute

\section{INTRODUCTION}

Agriculture has been backbone of every developing country like India. In India, maximum dependency of industries comes from farming and related activities. To provide technological support and advanced support system is the demand of this field. With newer advancements in the field of expert systems, it is viable that the yield of crops and disease management can be handled in a very smart way by the farmers themselves. For this advanced and intelligent farmer support systems are required. Also in India, the geographical factor such as region, weather, language and soil and crop type make it difficult to synthesize a single system with support for all these factors. Lot of digital information is available through ICT. This research focuses with following objectives.

\section{A. Need and Objective :}

This research focuses on following objectives:

1. To analyze the effectiveness of information and communication technology in agriculture.

2. To support the Digital India campaign initiated by Govt. of India.

3. To identify barriers to use digital media for growth.

4. To understand preferences for digital media( TV, Internet, Mobile, Web).

5. To minimize digital divide and improve usability of digital media, recommendations and design framework of service provider app or portal as E-Krishimitra.

\section{B. Interdisciplinary relevance:}

Interdisciplinary research is a type of study or research that draws from two or more disciplines in order to gain a more well-developed perspective, or discover something new. With the help of technological enhancement in the field of e-commerce, image processing, and ICT, this research focuses to provide easy access to information.

\section{REVIEW OF RESEARCH}

A. Review about portals and services:

- Kisan call Centre (Nationwide) [5]

Ministry of Agriculture launched the scheme "Kisan Call Centers (KCCs)" on January 21, 2004. Main aim of the project is to answer farmers' queries on a telephone call in their own dialect. A Kisan Knowledge Management System (KKMS) to facilitate 
correct, consistent and quick replies to the queries of farmers and capture all the details of their calls has been developed. Kisan Knowledge Management System (KKMS) has its independent web site http://dackkms.gov.in. The Kisan Call Centre (KCC) Agents working at various KCC locations throughout the country have access to this website through their specific ID's \& Password provided to them.

\section{- MKisan [8]}

Pervasive and extensive use of the ICT is an important tool of agricultural extension. Under the National e-Governance Plan - Agriculture (NeGP-A), various modes of delivery of e-enabled services have been envisaged. These include internet, touch screen kiosks, agriclinics, private kiosks, mass media, Common Service Centers, Kisan Call Centers, and integrated platforms in the departmental offices coupled with physical outreach of extension personnel equipped with pico-projectors and handheld devices. However, mobile telephony (with or without internet) is the most potent and omnipresent tool of agricultural extension. The project conceptualized; designed and developed in-house within the Department of Agriculture \& Cooperation has widened the outreach of scientists, experts and Government officers posted down to the block level to disseminate information, give advisories and to provide advisories to farmers through their mobile telephones. SMS Portal was inaugurated by the Honorable President of India on July 16, 2013 and since its inception nearly 50 crore messages or more than 152 crore SMSs have been sent to farmers throughout the length and breadth of the country. These messages are specific to farmer's specific needs \& relevance at a particular point of time. These messages generate heavy inflow of calls in the Kisan Call Centers where people call up to get supplementary information.

\section{- Agridaksh}

Sheridan or Maize Sheridan is a system developed by IASRI in collaboration with Directorate of Maize Research. It provides ICT based advisories on maize crop and allows interaction with experts using internet.

\section{- E-Chaupal}

Started by Stitch international Business Division as a cost-effective alternative supply chain system to deal directly with the farmer to buy products for exports is getting transformed into a Meta market for rural India. [7]

\section{Observations:}

With the help of technology many information and communication medias are available as a website portals or apps. There are some expert systems providing expert solutions. The approach of these systems is very specific. Integrated services are not available at one place for better use of technology. This reduces easy use and comfortable access to the information. The existing systems that are being used or deployed for providing expert solutions to the farmers with their farming activities are usually text or call based. The confidence for the expert systems is very low among rural households since they are digitally backward and unaware of what expert systems are capable of and what high potential they tap. Another way of looking on 
the available expert systems is that all the currently available systems have a niche area of application which focus on only one problem for example, pesticide selection, disease diagnosis, weather report, soil report. The approaches of these systems are very specialized and thus are area specific.

\section{B. Review about mobile apps}

Table 1: Mobile apps review[6][7][8]

\begin{tabular}{|c|c|c|c|}
\hline Sr. & App. & Features & Observations \\
\hline 1 & $\begin{array}{l}\text { Kisan } \\
\text { suvidha }\end{array}$ & $\begin{array}{l}\text { Call to (KKC) kisan credit Card. } \\
\text { Connection to net provides latest } \\
\text { information. }\end{array}$ & $\begin{array}{l}\text { Languages. } \\
\text { Frequent crashes }\end{array}$ \\
\hline 2 & Mkisan & Latest information are available. & App crashes. \\
\hline 3 & $\begin{array}{l}\text { Agro } \\
\text { connect }\end{array}$ & $\begin{array}{l}\text { Buy/sell feed. } \\
\text { Mandi prices. } \\
\text { Crop protection. } \\
\text { Advisory chat. } \\
\text { News feed. }\end{array}$ & $\begin{array}{l}\text { Weather forecast } \\
\text { alert system for natural calamities. } \\
\text { Government schemes. }\end{array}$ \\
\hline 4 & Crop info & Detail information of various crops & $\begin{array}{l}\text { Weather forecast. } \\
\text { Alert system for natural calamites. } \\
\text { News feed. }\end{array}$ \\
\hline 5 & $\begin{array}{l}\text { Kheti } \\
\text { Badi }\end{array}$ & $\begin{array}{l}\text { Weather forecast. } \\
\text { Organic agriculture produce pricing } \\
\text { FAQ's } \\
\text { Buy/sell organic products. } \\
\text { Information about farming. } \\
\end{array}$ & $\begin{array}{l}\text { Chat/expert suggestion/advice. } \\
\text { Alert system for natural calamities. } \\
\text { Live auction. }\end{array}$ \\
\hline 6 & $\begin{array}{l}\text { Kisan } \\
\text { market }\end{array}$ & $\begin{array}{l}\text { Min and max market prices of } \\
\text { products. } \\
\text { Weather report. } \\
\text { Product sell and purchase. } \\
\text { News feed } \\
\text { Farm guidance }\end{array}$ & $\begin{array}{l}\text { Alert system for natural calamities. } \\
\text { Government schemes. }\end{array}$ \\
\hline 7 & $\begin{array}{l}\text { Kisan } \\
\text { suvidha }\end{array}$ & $\begin{array}{l}\text { Live auction directly from apmc. } \\
\text { Weather information. } \\
\text { Daily/month wise prices. }\end{array}$ & $\begin{array}{l}\text { Weather forecast } \\
\text { Alert system for natural calamities. } \\
\text { Information about } \\
\text { government schemes. } \\
\text { Chat/expert suggestions/newsfeed. }\end{array}$ \\
\hline 8 & $\begin{array}{l}\text { Shetkari } \\
\text { masik }\end{array}$ & $\begin{array}{l}\text { Easy interface. } \\
\text { Easy downloads. }\end{array}$ & Only pdf files. \\
\hline 9 & Mkisan & $\begin{array}{l}\text { Latest information available for } \\
\text { farmers. }\end{array}$ & Connects directly to website. \\
\hline 10 & $\begin{array}{l}\text { Crop } \\
\text { indices }\end{array}$ & $\begin{array}{l}\text { Browse through various commodity } \\
\text { category. } \\
\text { Favorite a commodity. } \\
\text { Copy or share the mandi price in }\end{array}$ & $\begin{array}{l}\text { Not updated. } \\
\text { Not all states are covered. } \\
\text { Limited products. }\end{array}$ \\
\hline
\end{tabular}




\begin{tabular}{|c|c|c|c|}
\hline & & social media. & \\
\hline 11 & $\begin{array}{l}\text { IFFco } \\
\text { India }\end{array}$ & $\begin{array}{l}\text { It predicts weather along with } 5 \\
\text { days. } \\
\text { Provides latest news and } \\
\text { notification. } \\
\text { It provides multilingual with } 9 \\
\text { Indian languages. }\end{array}$ & $\begin{array}{l}\text { Default audio recorder is required for } \\
\text { audio enhancement. } \\
\text { While chatting, message sending } \\
\text { requires lot of time. }\end{array}$ \\
\hline 12 & $\begin{array}{l}\text { RML } \\
\text { Farmer }\end{array}$ & $\begin{array}{l}\text { By allowing location access to this } \\
\text { app it automatically sets the location } \\
\text { and language of the location. } \\
\text { It provides various features for } \\
\text { farmers. }\end{array}$ & $\begin{array}{l}\text { Not working properly on some } \\
\text { devices. }\end{array}$ \\
\hline 13 & Agri App & $\begin{array}{l}\text { Farmers can directly chat with } \\
\text { the scientist through this feature. } \\
\text { It provides secure payment. } \\
\text { Multilingual }\end{array}$ & Videos are not working properly. \\
\hline 14 & Agroster & $\begin{array}{l}\text { Free home delivery. } \\
\text { Multilingual. }\end{array}$ & App is slow. \\
\hline 15 & $\begin{array}{l}\text { Yara } \\
\text { check IT }\end{array}$ & $\begin{array}{l}\text { You can set your region or code } \\
\text { reader. } \\
\text { Almost all crops are covered. }\end{array}$ & $\begin{array}{l}\text { All information is provided on as "as } \\
\text { available" basis, without warranties of } \\
\text { any kind. } \\
\text { Multilanguage is not provided. }\end{array}$ \\
\hline
\end{tabular}

\section{RELEVANCE TO SOCIAL BENEFIT}

Technology plays important role in life changing process as information will be available to the people at one click. Indian population divided in urban and rural areas. Our food sector depends on the daily activities of the farmers in rural areas. This research focuses to improve farmer's life with the help of technology. Recommendations suggested and design framework suggested for development will change the livelihood of farmers. Comfortably they will be able to increase productivity. This will indirectly help to boost Indian economy.

\section{METHODOLOGY}

\section{This can be divided into four steps.}

\section{Step1 : Survey}

Survey has been conducted to understand digital compatibility in some districts of Maharashtra. Initially we selected farmers from Sangli, Satara, Solapur, Latur, districts of Maharashtra state. We had 170 sample sizes. Each district had been randomly covered with minimum 20 to 30 farmers with questionnaire. 


\section{Step2: Questionnaire Design and Interviews}

Following are few identified Research Questions and some more will be identified to support the research objective.

- How information and communication technologies be used to enhance the delivery of timely agricultural information?

- What types of information are most necessary for farmers?

- How is agricultural information delivered at present to these farmers?

- What are the problems farmers are facing to get access to the digital content?

- Is really this information useful for them?

- Suggest any improvements needed to increase effectiveness

- How the outcomes of this survey will be implemented on a wider scale and used to recommend proper solutions?

All these and some new if required, questions will be directly orindirectly covered in questionnaire. "PRASHNASANCH" .Sometimes it is very difficult to get exact and correct information through questionnaire. So interviews will be conducted to understand opinions of the farmers.

\section{Stpe3: Data Analysis [1]}

All data will be stored in SPSS or excel sheets. Analyze data using standard data analysis tools, Following are the phases involved in data analysis step.

- Categorize data according to type of questions.

- Question analysis by likert scale, mean square or standard deviation.

- Establish factors affecting the use of digital media

- Identify the more usable media.

This can lead to provide some solutions or recommendations to improve usability of digital content and minimize digital divide.

\section{Step4: Recommendations and Design of Service Provider Framework}

With the help of step1, step2, step3 recommendations will be provided to take decision for designing suitable Framework with digital gadgets.

\section{EXPECTED RESULTS}

To minimize digital divide and improve usability of digital media it is very important to understand, which are the most frequently used digital medias? What are the opinions of the farmers about the contents available with them? Which are the most likely communication medias? Is digital literacy affecting them? How digital content will help them to increase productivity? What are the best ways to make farmers life comfortable with the help of technology? With the help of this research we are trying to minimize digital gap and reducing lethargic attitude towards digital media. This leads us to encourage digital India campaign. 


\section{RESULTS AND DISCUSSION}

\section{A. Survey outcomes:}

Survey had been conducted for farmers in rural area. We considered four to five districts farmers from local area. Almost we got 170 responses. Questionnaire had been given to them. Responses recorded in excel sheet. With the help of graphical representation of collected data shown in figure 1 and figure 2. Following are some survey outcomes.

1. Mobile and TV are mostly accepted mediums of farmers. (w.r.t. Table 2 and Figure 1)

Table 2: Farmers and ICT Tools.

\begin{tabular}{|c|c|c|}
\hline ICT Tools & No. of Farmers & Percentage \\
\hline$T V$ & 129 & 34.4 \\
\hline Radio & 65 & 17.33 \\
\hline CD/DVD & 3 & 0.8 \\
\hline Internet & 56 & 14.93 \\
\hline Mobile & 95 & 25.33 \\
\hline Landline Phone & 3 & 0.8 \\
\hline Computer & 18 & 4.8 \\
\hline News paper & 6 & 1.6 \\
\hline Total & 375 & 100 \\
\hline
\end{tabular}

No. of Farmers and Percentage

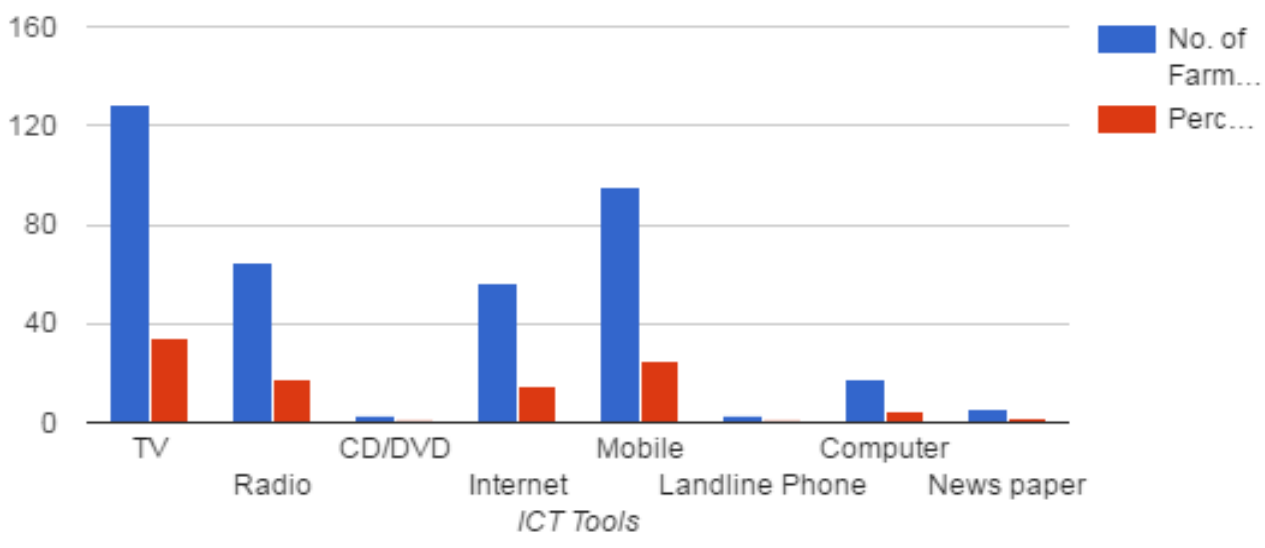

Figure 1: Farmers and ICT Tools Preference.

1. Farmers are comfortable with mouth publicity and individual help. ( w.r.t. Table 2 and Figure 2) 
Table 3: Reliability of Information.

\begin{tabular}{|l|c|c|}
\hline $\begin{array}{l}\text { Main Agricultural } \\
\text { Information Providers }\end{array}$ & No. of Farmers & Percentage \\
\hline Neighbours & 89 & 31.56 \\
\hline Agriexperts & 95 & 33.69 \\
\hline Agriculture extension workers & 36 & 12.76 \\
\hline Agriculture agents & 1 & 0.35 \\
\hline Govt. offices & 28 & 9.93 \\
\hline Websites & 17 & 6.03 \\
\hline Others & 16 & 5.67 \\
\hline Total & 282 & 100 \\
\hline
\end{tabular}

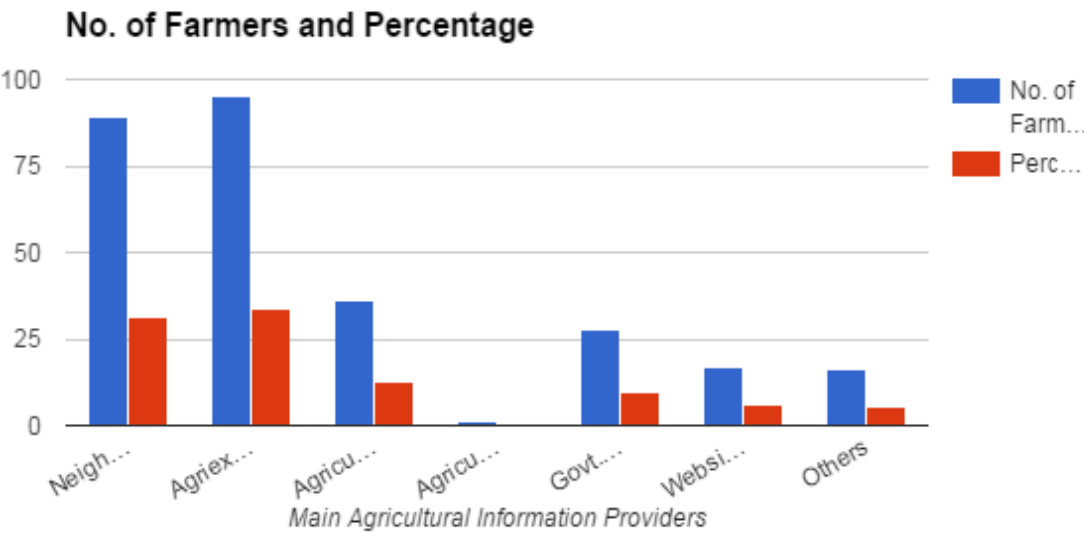

Figure 2: Reliability of Information

2. Required services are pest management, useful fertilizers, weather forecast, soil improvement etc. ( w.r.t. Table 4, figure 3)

Table 4: Services Needed

\begin{tabular}{|l|c|c|}
\hline Improve productivity and usability & No. of Farmers & Percentage \\
\hline Pest management & 122 & 73.93 \\
\hline Market price & 37 & 22.42 \\
\hline Useful fertilizer & 107 & 64.85 \\
\hline Financial management & 67 & 40.61 \\
\hline Whether forecast & 98 & 59.39 \\
\hline Soil improvement & 85 & 51.51 \\
\hline Organic farming & 68 & 41.21 \\
\hline Others & 8 & 4.84 \\
\hline
\end{tabular}




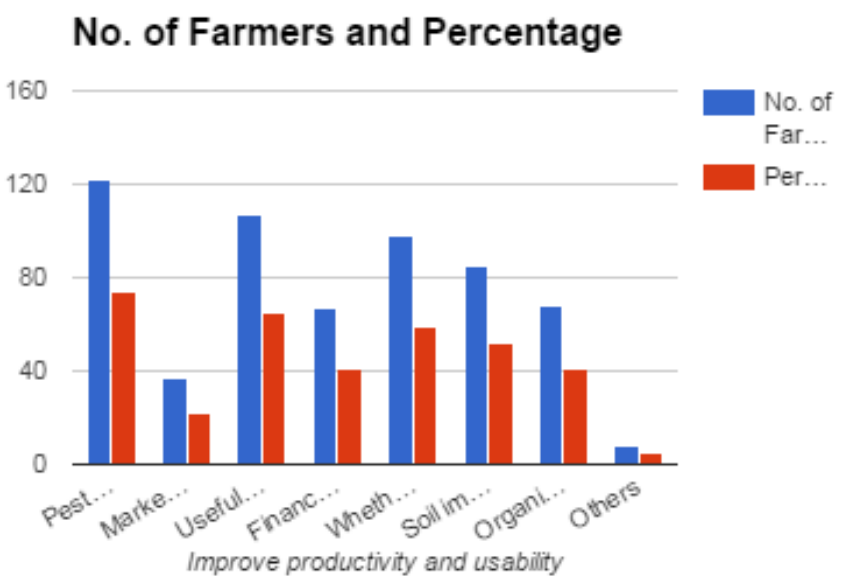

Figure 3: Needed Services

Primary observations with survey and interview says that,

3. People are not very handy to use technology.

4. Language barrier in information.

5. Low literacy.

\section{B .Recommendation to design framework:(E-Krishimitra):}

With the help of survey outcomes, following factors will be considered to design and implement E-Krishimitra tool.

- Designing and developing mobile app and web site.

- Discussion forum through app. and website.

- Online as well as offline help to bridge the gap between knowledge and technology with ease of use.

- IVR or Multilingual support (local language).

- For illiterate people information will be provided in all medium. (Image/ audio/ video.)

\section{CONCLUSION AND FUTURE SCOPE}

To improve usability of knowledge shared by different digital media and to minimize digital divide questionnaire named as "Prashnasanch "has been designed. With the help of "Prashnasanch " survey has been conducted .The outcome of survey helped to find out problems related to usability of digital contents published through digital media. Survey had been conducted in rural areas of Sangli, Solapur Satara districts. With collected data, data analysis has been done to solve identified research questions. With the help of tables 2,3,4 solutions and recommendations will be provided for the development of mobile app or website portal as a "E-Krishimitra " which can be helpful for them in day to day life. . We can implement a system which has a high level of usability since the system diminishes the barrier of language which causes major implementation issues in the Indian sub-continent. 


\section{REFERENCES}

[1] Khumphicha Tantisantisom.'Information Dissemination for Farming Communities in Thailand" Thesis, Edith Cowan University, Aug 2011.

[2] "E-Agriculture" A Definition and Profile of its

[3] Application World Summit on the Information Society, Geneva 2003 - Tunis 2005 ,

[4] Sh. Ghanshyam Goel ADG (M\&C), PIB Sh.

[5] Samrat Bandopadhyay, Assistant Director (M\&C), PIB New Delhi.(PIB Features), published Article. SS-319/SF-319/28.04.2015 YSK/ Uma.

[6] Er. Ramanjeet Kaur "Importance of Expert

[7] Systems used in Agriculture."International Journal of Enhanced Research in Science Technology \& Engineering,ISSN: 2319-7463Vol. 3 Issue 5, May2014, pp: (265-269),

[8] "Kisan call center" Accessed: 15 May 2015

[9] "Agriculture app" Accessed: 15 May 2015

[10] "Agricoop" Accessed: 15 May 2015

[11] “m kisan” Accessed: 15 May 2015. 